\title{
Morphology Data Collection Date Time
}

National Cancer Institute

\section{Source}

National Cancer Institute. Morphology Data Collection Date Time. NCI Thesaurus. Code C117629.

The date and time morphology data was collected. 